park next to its genetics research centre at Hinxton Hall near Cambridge. The planning inspector has rejected the proposal. But this decision has yet to be endorsed by Prescott.

Another battle looms over biotechnology regulation. The environment department plans to include more public representatives on its committee of scientists that advises the government on the safety of proposed genetically modified crops.

It also wants applications to grow such crops to be seen by an additional ethics committee. But the Department of Trade and Industry (DTI) is likely to oppose this on behalf of industry, which fears that further regulations will be time-consuming and a threat to economic competitiveness.

This battle will be fought out in a forthcoming review of the structure of Britain's biotechnology regulatory system, also announced last week. The review, to be carried out by the Cabinet Office and the Office of Science and Technology, will include public consultation on the regulatory process.

It has been set up partly in response to the collapse in public confidence in government science advice during the crisis over bovine spongiform encephalopathy, and partly to address public concern that regulations on the planting of genetically modified crops do not adequately address safety issues.

One senior environment civil servant says the spectre of a possible recession is one reason that the DTI is keen to help set up knowledge-based companies. But she says her department will face severe public criticism if environmental and safety considerations are relaxed.

Ehsan Masood

\title{
Foresight initiative goes for competitiveness
}

[LONDON] The British government last week chose the occasion of the publication of its white paper on industrial competitiveness (see left) to launch the second phase of its Foresight exercise.

The Foresight initiative was launched by the previous Conservative government with the aim of stimulating scientists and industrialists to think about how science can be better targeted at creating wealth and improving the quality of life.

The Department for Education and Employment has written to the highereducation funding councils saying that it expects them to promote Foresight, and to take appropriate steps "to maximize the commercial exploitation of university research".

This is among the first signs that Foresight priorities, which have come to dominate the allocation of the annual $£ 1$ billion (US $\$ 1.68$ billion) research budget from

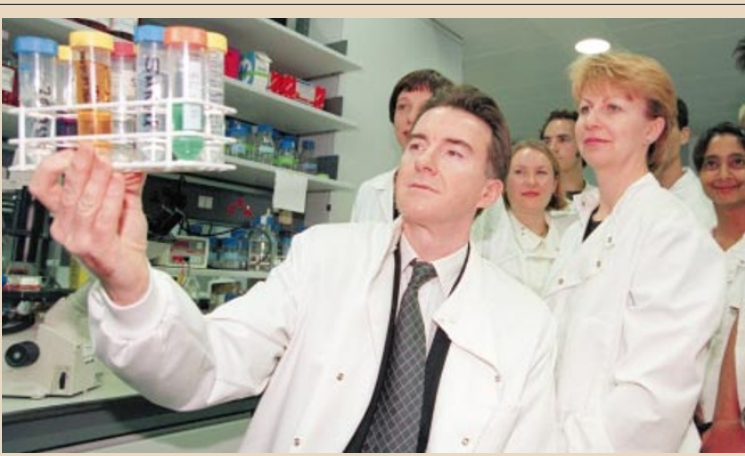

Admiring progress: Mandelson visits a cancer research lab.

the four scientific research councils, will also influence the education department's research allocations.

The decision to launch the new Foresight exercise illustrates the government's commitment to its usefulness as a device for structuring research policy. But there is some unease within the Office of Science and Technology over the 'spin' given to it by Peter Mandelson and Lord Sainsbury in their presentation of the launch.

Both ministers emphasized Foresight's potential contribution to economic competitiveness But the second phase had initially been designed under Mandelson's predecessor Margaret Beckett, to tone down this aspect and to increase the emphasis on finding ways of using research to raise the quality of life (Nature 393, 8; 1998).

The emphasis is less on finding technologies that would benefit particular industrial sectors, and more on getting scientists and industrialists to focus on various interdisciplinary 'themes' such as ageing, healthcare and crime prevention.

\section{Canadian whistleblower row prompts broader code of conduct}

[MONTREAL] The Medical Research Council of Canada (MRC) is to attempt to broaden the ethical code of conduct for research involving humans that it published in September (see Nature 395, 420; 1998). The decision follows a dispute between a clinical researcher, the pharmaceutical company funding her research, and the hospital where the research took place.

At present, the MRC code covers only research funded by itself and the two other principal fund-granting agencies, the Natural Sciences and Engineering Research Council and the Social Sciences and Humanities Research Council. It now wants the code to cover all research involving humans, regardless of who funds it. This is becoming increasingly important as government funding for research is being replaced by funding from industry.

The move follows a request for help from Toronto's Hospital for Sick Children to Henry Friesen, president of the MRC, following the release of a report about the activities of Nancy Olivieri, a researcher who had been carrying out clinical studies of the drug deferiprone in the treatment of thalassaemia.

When Olivieri went public with warnings that the drug could cause liver fibrosis, Apotex, the drug's manufacturer which was paying for the research, disagreed with her findings and threatened her with legal action because she had signed a confidentiality agreement.

Olivieri claims that the hospital refused her legal aid to defend herself, a charge the hospital denies. When her research colleagues backed her, a public furore erupted. Olivieri and her supporters called for an independent inquiry into the affair but the hospital refused, agreeing only to set up an investigation of hospital policies and practices in general.

The hospital later changed its mind, and agreed to set up an inquiry into the affair itself. But Olivieri and her supporters refused to participate, claiming that the panel leader, Arnold Naimark, professor of medicine and physiology at the University of
Manitoba, had previous links with Apotex funds and so was not impartial.

On 9 December, the hospital released the panel's report, which exonerated the hospital from improper conduct, and said that patient safety was not compromised and that there were no conflicts of interest. But the report acknowledged the need to improve some hospital policies.

The report also criticized Olivieri for failing to report her concern about liver toxicity promptly to its Research Ethics Board. But Olivieri calls the report a whitewash.

Olivieri says that she and her colleagues refused to participate in the inquiry because of conflicts of interest on Naimark's part that she says are a matter of public record. "All the people with intimate knowledge of what happened were never questioned," she said.

She and her colleagues are determined to get an independent investigation into the matter. Observers say the affair illustrates the dangers of increasing industrial support for research in Canada. David Spurgeon 